\title{
The Permanent People's Tribunals and indigenous people's struggles in Mexico: between coloniality and epistemic justice?
}

\author{
Rosalba Icaza ${ }^{1}$
}

ABSTRACT On 21 October 2011, hundreds of Mexican civil society organizations formally submitted a petition to the Lelio e Lisli Basso Foundation in Rome to justify the opening of a Mexican Chapter of the Permanent People's Tribunals (PPT). The PPT was established in 1979 as the successor to the Russell Tribunals on Vietnam (1966-1967) and on the Latin American Dictatorships (1974-1976). The PPT is considered an ethical non-governmental tribunal and their sessions are described as a mechanism for raising awareness of national and international public opinion on rights violations. This article investigates the potential of the PPT for contributing to epistemic justice in Mexico, by focusing on indigenous people communities' long-term struggle for legal pluralism and autonomy. In so doing, it offers an analysis about the coloniality of international human rights law operating in nongovernmental mechanisms of popular litigation such as the PPT; a perspective that has remained absent in critical international and global studies. In particular, the article argues that the PPT in Mexico is imbricated with Eurocentric modes of legal production but that it nonetheless has the potential to contribute, in a relevant but fragile way, to epistemic justice. On the one hand, it is observed that PPT key documents and statements explaining different forms of violence in Mexico emphasize causal relationships based on the all-encompassing power or logic of capitalism. This perspective, it is argued, has the effect of epistemic erasure: notions and practices of justice that exceed this logic are silenced in the process of legal translation for the construction of "model cases". On the other hand, the article highlights the coexistence of different notions of justice in one of the PPT thematic hearings on Violence against Corn, food sovereignty and autonomy hold in Oaxaca, Mexico, to argue for a re-thinking of the monocultural state-centric legal frames that ground PPT legal qualification. As the PPT classify social grievances in legal terms through the lens/gaze of international law, this legal qualification works as an activity of "translation", in some cases of incommensurable notions of justice or absence of justice, violence or well-being. The article concludes with an emphasis on the potential contributions of the PPT to epistemic justice as the political visibility of the many ways in which justice is understood and experienced despite the many forms of violence and oppression in contemporary Mexico.

\footnotetext{
${ }^{1}$ Institute of Social Studies, Erasmus University of Rotterdam, The Hague, The Netherlands (e-mail: icaza@iss.nl) A preliminary version of this article was presented at the Expert Seminar on People's Tribunals and International Law held on 27-28 September 2013 at the Lelio e Lisli Basso Foundation in Rome, Italy.
} 


\section{Introduction: The Permanent People's Tribunals in Mexico}

... esperando su inevitable indignacion, para que la impotencia que hoy nos asfixia a la mayoria de los mexicanos, se torne en una consecuente accion global $^{1}$

n 21 October 2011, hundreds of Mexican civil society organizations formally submitted a petition to the Lelio e Lisli Basso Foundation in Rome to justify the opening of a Mexican Chapter of the PPT. Almost 1 year later, the General Hearing of the PPT took place from 27 to 29 May 2012 in Ciudad Juárez, in the Northern state of Chihuaha under the name "Dispossession and Predation of Mexico. Free Trade and Power Deviation as causes of structural violence, impunity and dirty war against the people of Mexico". 2

The PPT Mexican Chapter was organized around seven thematic hearings, including Femicide and Gender Violence; Migration, Refugee and Forced Displacement; Environmental Devastation and Peoples' Rights; Violence against Workers; Misinformation, Censorship and Violence against Communicators; Dirty War as Violence, Impunity and Lack of Access to Justice; and Violence against Corn, Food Sovereignty and Autonomy. The Final session of the PPT took placed 3 years later in November 2014. The organizers stressed in the opening remarks of the final ruling document that the PPT was marked by "the shadow of the tragic events of Ayotzinapa, Guerrero" (TPP Capitulo Mexico, 2014). ${ }^{3}$

The PPT was established in 1979 as the successor to the Russell Tribunals on Vietnam (1966-1967) and on the Latin American Dictatorships (1974-1976). The PPT was created out of the realization that "law and justice in many circumstances cannot be trusted to the State and their institutions" (TPP Capitulo Mexico, 2012a). The PPT's sessions seek to react to the suffering of people "produced by State and government oppression, but also by private enterprises, banks and international financial institutions" (TPP Capitulo Mexico, 2012a).

The PPT as an ethical non-governmental tribunal "examines the causes behind the violation of fundamental rights of peoples and determines if these rights have or not been violated" (TPP Capitulo Mexico, 2012a, b). The PPT sessions are also described as a mechanism for raising awareness of national and international public opinion on rights violations. "The mission of the Tribunals is to promote universal and effective respect of fundamental rights of peoples, minorities and individuals; and work for the generation of law that protect those rights" (TPP Capitulo Mexico, 2012a). ${ }^{4}$ In so doing, the Tribunals qualify situations in legal terms contributing to the identification of duty and rights holders in relation to situations when these are not apparent like in the case of human rights violations committed by local authorities to protect transnational corporations fiduciaries' interests (Icaza, 2010).

By attributing responsibility to particular actors with faces or brand names, these mechanisms of popular litigation have contributed to question what feminist political economist Bergeron (2006) theorizes as the dominant script of neo-liberal globalization that is represented as an abstract dominant and unified force/system (Icaza, 2010). This possibility of attribution has been a central aim of the PPT in Mexico given the context of impunity and violence as the following quote from the final ruling document displays: "In this realm of impunity that is today's Mexico, there are murders with no murderers, torture with no torturers, sexual violence with no abusers, in a constant abdication of responsibility, in which it would seem that the thousands and thousands of massacres, murders and systematic violations of the rights of peoples are always isolated acts or marginal situations rather than true crimes for which the State bears responsibility" (TPP Capitulo Mexico, 2014).

Following the work of feminist decolonial philosopher and popular educator Lugones (1990, 2003), I have argued elsewhere that the mere act of questioning dominant discourses and scripts on globalization is one of the ways in which the PPT contribute to global cognitive or epistemic justice (Icaza, 2010). In short, cognitive or epistemic justice is mainly understood here as necessary to (Santos et al., 2007) one has to deal with the erasure of knowledge and ways of being in the world, including notions and practices of justice outside the nation state's legality, which have been produced as "backward", "traditional", "other" or "particular" in relation to a supposedly "universal" knowledge (Santos, 2006; Hernandez et al., 2013). More precisely, this article seeks to explore ways in which the PPT in Mexico is imbricated with Eurocentric modes of legal production, ${ }^{5}$ but that nonetheless contributes, in a relevant but fragile way, to epistemic justice.

\section{PPTs and the coloniality of international law}

In Anglo-Saxon academia, the Gayatri Spivak's essay, "Can the Subaltern Speak?" has been a central reference for understanding the power of discourse in the subalternization of difference and more specifically on the role of intellectuals in representing the "subaltern". To date, Spivak's ideas constitute a crucial reference in postcolonial analyses of cotemporary forms of epistemic violence (Spivak, 1988).

This article's interest in PPTs contributions to epistemic justice connects with two traditions of critique that belong to a different geo-genealogy ${ }^{6}$ to that of postcolonial studies: decolonial thinking (Quijano, 2000; Mignolo, 2003, 2013; Vázquez, 2009; Lugones, 2010a, b; Walsh, 2007, 2010, 2012; Vázquez, 2011, 2014) and the epistemologies of the South (Santos, 2006, 2009; Santos et al., 2007).

In this sense, I am writing from an epistemic location that questions the "modern" version of "history" that places the British Empire (or sometimes the French empire) at the centre of the modern/colonial history and that goes back three centuries to when Abya Yala (the Americas) was conquered in 1492 and the genocide of millions of indigenous peoples, their knowledge and ways of being in the world took place (Quijano, 2000; Mignolo, 2003). This epistemic location acknowledges that modernity has its "underside", coloniality and as such it is not just the fortunate product of the Renaissance or the Industrial Revolution.

Modernity/Coloniality has been understood as a co-constitutive binomial and a structure of management that operates by controlling the economy, authority (government, politics); knowledge and subjectivities; gender, sexuality (Quijano, 2000; Mignolo, 2013). From this perspective, the "coloniality of power" explains that "the basic and universal social classification of the population of the planet in terms of the idea of 'race' is introduced for the first time" with the Conquest of the Americas (Lugones, 2010a: 371). This analysis "has displayed the heterogeneous and transversal character of the modern/colonial system" (Vázquez, 2014: 176) counterpoising racial domination to the Eurocentric Marxist theory of class exploitation.

Nonetheless, when modernity/coloniality is understood not only as a co-constitutive binomial but also as two different movements or forms of relationship with reality, it is possible to highlight their different locus of enunciation: the historical movement of modernity as from which hegemony and privilege has named reality, for example, the name given to the peoples inhabiting Abya Yala as "Indians" and more recently 
"indigenous" or "minorities". Meanwhile, the historical movement of coloniality is understood as the locus from which the negation of realities and worlds otherwise that exceed the dominant modern geo-genealogy of modernity takes place, for example, when normative systems outside or in the margins of the nation-state are denied validity (Vázquez, 2014).

From this perspective, modernity is "the name and narrative that the western civilization project with totalizing pretensions gives to herself and to the representation of the world", while coloniality is "not a mere abstraction ... is the group of historically concrete practices and forms of exclusion exercised by the modern/colonial project ..." (Vázquez, 2014: 175-179). Precisely, in this article, I seek to understand concrete practices of epistemic exclusion operating in the PPT Eurocentric modes of legal production, but also if epistemic justice is possible given such exclusions.

Following these ideas, I understand epistemic justice as taking place when forms of being in and seen the world that have been turned invisible or subalternized by modernity/coloniality are brought into the light of the public. "The struggles for epistemic justice seek to break down hierarchies and exclusions related to dominant forms of representing the world and the imposition of certain historical values, knowledges and views of the world" (Icaza and Vázquez, 2013).

The PPT are seen as mechanisms and processes with the potential for contributing to epistemic justice in as much as these break down hierarchies and exclusions related to the plurality of understandings about what is supposed to be justice (Icaza, 2010). An emphasis on the contributions of the PPT sessions to epistemic justice would mean then to give attention to the ways in which these contribute to the visibility of the many ways in which justice is understood and experienced, despite the many forms of violence of capitalism and/or state authority.

Following Santos' (2006, 2009) ideas, Vázquez (2009) has argued that the struggles for social justice are struggles for "political visibility", a term that makes reference to "bringing the claims for justice into the light of the public" and that "signals the close relation that there is between the material means of oppression and epistemic discrimination" (italics added). This is a clear attempt to connect oppressions and resistances transcending the explanations on causal relationships based on the all-encompassing power or logic of capitalism. As will be observed, this "intersectional" approach is absent from PPT key documents and statements that explain different forms of violence in Mexico. This absence has the effect of epistemic erasure as notions and practices of justice that do not fit in or exceed the all-encompassing logic of capitalism are silenced in the process of legal translation for the construction of a legal case of "power deviation" (see TPP Capitulo Mexico, 2006, 2012b, 2014).

\section{A decolonial feminist perspective on PPTs}

A feminist critique and expansion of Mignolo and Quijano's understandings on the coloniality of power explains it not only as the intersection of oppressions and power that classifies people according to race, but also to the European heterosexual standard (Lugones, 2010a).

From this perspective, decolonial feminist theorizations on social resistance to coloniality's intersected oppressions has managed to pose important questions to a supposedly unitary and all-encompassing (capitalist and/or state) power system by bringing to the fore the fragmented characteristic of self-identities and consciousness (Lugones, 1990, 2003). Resistance acts are seen as taking place against multiple sites of oppression and power through multiple identities, consciousness and the fleshy reality of a racialized and subalternized body. In other words, one can be a male Mixe indigenous person belonging to a community of radio communicators, who is actively struggling against local state repression that favours capitalist accumulation by the dispossession of communal lands and racism. At the same time, this activist can make use of some means of the local state's legal system that condemns public disobedience as an illegal act.

Accordingly, the theoretical move that I aim to introduce here stems from situated experiences of multiple intertwined forms of oppression (sexism, classism, racism, heteronormativity and so on) and implies the possibility of challenging modern/colonial totalizing narratives of a unitary system of oppression, being this capitalism, globalization, heteronormative patriarchy and so on (Lugones, 1990, 2003, 2010a, b).

Furthermore, this feminist perspective opens up the possibility of going beyond traditional political-economy paradigms, which conceive of capitalism as an all-encompassing global or world system (Grosfoguel, 2007). From this perspective, social struggles to oppressions are primarily represented as reactions to the structures of (capitalist) oppression, and only secondarily as alternative political practices based on life experiences (Icaza and Vázquez, 2013).

\section{Dialogue on the PPTs in Mexico: is it worthwhile? ${ }^{7}$}

With the above ideas in mind, I have argued that the PPT's sessions are contributing to epistemic justice through practices that allow for the political visibility of knowledge (and not only of testimonies of violence) that otherwise would have remained ignored or produced as non-existent (Icaza, 2010). This was specifically observed in relation to the Tribunal's sessions on European Multinationals and Neoliberalism and their hearings in Vienna (2006) and Guatemala (2008) in which a number of cases related to communities and peoples of indigenous nations and African descent received a great deal of attention in the Tribunals processes, discussions and rulings. An example of this was the reflections on Andean indigenous conceptions such as el buen vivir (the fullness of life) in the final report of that PPT (Walsh, 2007; Icaza, 2010).

However, this contribution to epistemic justice of the PPT is not free from tensions. The tribunals classify social grievances in legal terms through the lens/gaze of international law. This legal qualification works as an activity of "translation", in some cases of incommensurable notions of justice or absence of justice, violence or well-being. This bears the potential of erasing and making invisible what does not fit or seems problematic to attach to a particular international law (Santos et al., 2007). This is what has been termed "translation as epistemic erasure" (Vázquez, 2011). In practical terms, this erasure might be subtle and not premeditated, but it has certainly taken the form of selection of "model cases" due to their relevance in terms of their legal analysis (Icaza, 2010).

These ideas-the PPT's contribution to epistemic justice is not free from tensions such as the risk of legal qualification as a form of epistemic erasure-are now the entry point into my analysis of the PPT in Mexico. ${ }^{8}$ My exploration started back in 2010 with a brief conversation I had with a feminist academic-activist closer to the struggles of Zapatista indigenous women about the plans that a group of Mexican feminist organizations had to submit a request to bring the PPT to Mexico to judge the case of femicides. Our main common concern was the extent to which the PPT's (modern/colonial) legalist vocabulary and Eurocentric rationality would allow the coexistence of pluriversal notions of justice beyond an international human rights perspective. After the first pre-hearing of the PPT on Feminicide and Gender Violence in 2012, we exchanged some ideas and written texts, and despite doubts she participated in the PPT. ${ }^{9}$ I remained as a critical supporter 
based in the Netherlands and followed the PPT developments in the Mexican press, social media and through email conversations with other academics and activists supporting them.

In mid-2013, I had the opportunity to travel to Oaxaca, Mexico, to the Universidad de la Tierra (http://unitierra.blogspot $. \mathrm{nl} /)^{10}$ (Land University) and discussed the above-expressed concerns with some of the organizers, participants and a judge of one of the hearings of the PPT sessions in Mexico on Violence against Corn, Food Sovereignty and Autonomy. My main question to them was: Is it worthwhile to bring the PPT to Mexico amidst the ongoing struggles for the recognition and autonomy of indigenous systems and practices of justice? Like the feminist academic-activist, they expressed their hesitation but also their firm commitment to the PPT process.

As such, this article is a first attempt to systematize what has been a personal learning process, but one that arises from and in relation with PPT participants on the potential contribution of the tribunals to epistemic justice in Mexico. This approach to learning with, instead of about, activists and social movements has been termed collaborative research, committed research or activist research (Leyva and Speed, 2008; Barbosa et al., 2015).

In so doing, I write this text as a dialogical process ${ }^{11}$ and as a critical supporter and promoter of PPTs in Mexico, but one that is based in the Global North. Therefore, I use a question mark in the title to indicate that the PPT tension between coloniality and epistemic justice contributions is not at all a closed question but a troubled position that is explored from a privileged position in Global North academia with all the privileges and limitations that this entails (Icaza, forthcoming).

In the process of writing this article, three other questions emerged:

(a) In which ways does a [deep] questioning of an allencompassing state-centric and/or capital-centric narrative of "a" system of power unveil the limits of universalisms, including "international human rights law"?

(b) Can the PPT's ways of working allow/facilitate/encourage the political visibility of a pluriversality of forms in which life is organized, experienced and ruled in Mexico?; and

(c) Why is it necessary to reflect on this critique of international human rights in the framework of the PPT to preserve its relevant but fragile contribution to epistemic justice?

A fourth and fifth question emerged from the series of email exchanges with one key organizer of the PPT, who was hesitant about the relevance of my ideas given the context of impunity and violence towards human rights activists in Mexico, and who actually questioned me: Is your analysis worthwhile? For who is it relevant? Therefore, the question mark in the title also aims to highlight that the epistemic position that is taken here starts with a questioning of who has had the power and the right to formulate the questions in the geopolitics of knowledge. ${ }^{12}$

To address some elements of these questions, I have divided the rest of this article in four sections. To start addressing the first two questions, I first analyse the PPT's public statements and the documents produced by the organizations involved in the proceedings in Mexico. This analysis is conducted to understand how the problem of dispossession and violence in Mexico is explained by those who asked the presence of the PPTs in Mexico as a means of popular justice given the context of impunity and violence. In particular, in this section it is asked which analytical perspectives are privileged, and what remains silenced in the process of legal translation for the construction of power deviation as a "case" to be judged from the perspective of international human rights law.

The next section presents alternative ways in which the judges and organizers of the PPT's hearing on Violence against Corn,
Food Sovereignty and Autonomy paved the way towards some sort of epistemic justice by contributing to the political visibility of a pluriversality of forms that organized and normed life around corn in Mexico.

The subsequent section reflects on the limits and perils of universalism in human rights law identified by critical interculturality approaches. Walsh describes critical interculturality as opposed to functional interculturality. The latter is "an institutional strategy that seeks to promote dialogue, tolerance, coexistence, and inclusion without necessarily addressing the causes of inequality; it makes diversity 'functional' to a system". Meanwhile, a critical inter-culturality perspective "initiates with a profound questioning of the system [of inequality and exclusion] and seeks its major transformation in social, political, epistemic, and existential terms" (Walsh, 2007: 21).

This brief introduction of critical inter-culturality allows me to move to the section "The PPT in Mexico and the coexistence of many forms of violence" in which I present some of the contemporary challenges and dilemmas faced by indigenous' communities struggling for legal pluralism and autonomy in Mexico. The final section offers some reflections on this article's argument and epistemic position.

\section{The PPT in Mexico and the coexistence of many forms of violence}

In the General Indictment (Acusacion General) of the PPT Mexican Chapter presented in the General Hearing, the current context in Mexico is characterized by the coexistence of different forms of violence. Violence related to drug trafficking and the Mexican state's war against drug traffickers coexist with economic forms of violence that are manifested in huge disparities in levels of income distribution, the state of crisis in the process of social reproduction, the squandering of communal goods and so on. Parallel to this, a rapid trend towards the violent and fast degradation of natural resources through the contamination with industrial and housing residual toxics of vast amounts of land, water and soil is described. In the case relating to violence towards corn, this is presented as a top-down process of contamination through genetically modified strains introduced by multinational corporations such as Monsanto, Dupont, Novartis and Aventis with the active support of the federal and local authorities (TPP Capitulo Mexico, 2012b). Moreover, violence related to difference including ethnic, gender and sexual orientation is described as direct forms of physical abuse, such as hate crimes and femicide, and more subtle forms of discrimination that include acts of racism, sexism and classism, which lead to the exclusion of vast sectors of the Mexican population from public and private institutions, services and public space.

The General Indictment carefully documents these different forms of violence and describes the current context in Mexico as a humanitarian crisis due to the ongoing structural violence (TPP Capitulo Mexico, 2012b: 2). Inspired by what seems to be Galtung's (1969) perspective of structural violence, this is presented as mainly a product of processes of neo-liberal restructuring expressed in the form of liberalization, deregulation and privatization policies. The North American Free Trade Agreement signed between Canada, Mexico and the United States in 1992 deserves special attention as one of the policies that produces direct forms of violence, including the one exercised against collective property of land, means, practices and institutions of popular subsistence, forced displacement of peasants from rural to urban areas and so on.

The main objective of the document is to demonstrate the "complex causal relationship between the humanitarian and socio-political catastrophe that characterized the country" 
(TPP Capitulo Mexico, 2012b: 4). In doing so and according to Galtung's views of structural violence as "avoidable", the document emphasizes the "reiterative, sustained and systematic forms through which the Mexican state has promoted an economic liberalization policy, trade liberalization, privatization, denationalization of public goods and stabilized inflation" in accordance with the so-called Washington Consensus framework (TPP Capitulo Mexico, 2012b: 4). Moreover, "the document argues that the Mexican state adopted various policies which were not democratic or legitimate and which led to negative economic and socioeconomic outcomes, with the result that it is the state that bears primary responsibility for the resulting humanitarian disaster".

These voluntary state acts are presented as the causes behind what is conceptualized as deviation of economic and political power (TPP Capitulo Mexico, 2012b). This power deviation as specific crime attributed to the Mexican state is qualified as "a crime that unfolds silently and invisible ... by its own nature and mechanisms it is a crime that, despite the empirical evidence, seems not to have been perpetrated and hence, those who are responsible appear not to be so" (TPP Capitulo Mexico, 2012a, b: 10). ${ }^{13}$ This is an important qualification of the nature of state power deviation and as such it contributes to a denaturalization of violence in Mexico by displaying the processes, mechanisms, decisions or lack of decisions taken by state actors and institutions as conducive to different forms of violence.

Overall, it is possible to assert that from this document's perspective violence in Mexico is the product of two decades of neo-liberal restructuring and its accompanying logic of modernization. One can hardly deny that such a view is accurate. However, as it is explained below, this perspective silences a radical questioning posed by experiences that have been produced as non-existent by certain narratives about the state, capitalism and power.

\section{The silences and non-visible sides}

According to the General Accusation, the deviation of economic and state power is an "abnormal attitude" (actitud anómala) through which the state "makes use of its functions and powers (sic) to benefit particular interests which, are contrary to and harmful to the general interest that it is supposed to protect" (TPP Capitulo Mexico, 2012b: 5). ${ }^{14}$

On the one hand, this view of the state as a perpetrator of the crime of power deviation as an abnormal situation seems to be grounded in a particular view of the state that is blind to the process that founded the modern/colonial Mexican state, one characterized by the systematic exercise of force and violence, genocide, dispossession and predation. This characterization of the present situation as abnormal is persuasive only if one does not take into consideration the experiences and perspectives of those systematically excluded from the modern/colonial project of nation-state building in Mexico: indigenous people and their communities, women and all those sectors of society not represented by the liberal notion of (male/urban/propertied/ heterosexual) citizen. Unfortunately, the view of the state that permeates the document fails to recognize the state as a mechanism of control and violence, of exclusion in the name of "national" unity and cultural homogenization (Villoro, 1998; Lopez Barcenas, 2005). An example is the creation of provinces (estados) and municipalities (municipios) that divided indigenous peoples in Mexico. This view remains central despite the fact that two of the main cross-cutting topics of the PPT in Mexico are indigenous peoples and their territories, and of course gender (TPP Mexico, 2011: 26).

The General Accusation is also silent on the systematic attempts through techniques of control including schooling, health and law, which have produced as non-existent those who are considered inferior or "backward" together with their forms of organization, knowing, being, living and feeling (Santos, 2002; Vázquez, 2009; Icaza, 2010).

Finally, in the PPT's General Indictment, ethnic and genderrelated discrimination and racism are mostly understood as by-products of systemic or structural logics of capitalist dispossession. These are far from been understood as interconnected forms of oppression.

For example, when the PTTs General Indictment document argues for a criminal case against the Mexican state, it does so through a construction of a hierarchy of causalities in which the structural-read as capitalism and particularly its current overaccumulation crisis-is the key causal force behind everything else. Of course, one can agree with this capital-centric view or not. What matters here is that such a view produces as residual or in the worst case simply renders invisible the complex interrelations between capitalism/racism/sexism/eurocentrism and the violent oppressions that result from these intersections. These are vividly manifested, for example, in acts of physical violence against indigenous women's bodies or in the forced displacement of indigenous communities from their ancestral territories, issues that were central to two of the thematic hearings conducted by the PPT. Interestingly, these were named "themes" not "logics" or "causes", and as such are not given the same explanatory power as capitalism over accumulation to understand the different forms of violence in contemporary Mexico. ${ }^{15}$

\section{The many layers of violence and resistance}

Paradoxically, in the PPTs there was also the possibility of a complex view of the intersections between capitalism/racism/ sexism/eurocentrism. This was the case of the PPT thematic pre-hearing on Violence against Corn, Food Sovereignty and Autonomy conducted in San Luis Beltran, Oaxaca, Mexico on 26-27 April 2013 under the name Transgenic Contamination of Native Corn.

In the dictamen produced by Camila Montesinos, Joel Aquino and Gustavo Esteva (Aquino et al., 2013) as judges in this prehearing, it is also possible to find many coincidences and continuities in the attribution of the specific crime of power deviation to the Mexican state. The document clearly states in relation to state's deviation of power "we can demonstrate with the evidence that we have received [that] it has been misused through new laws and through policies and programs ... which are clearly against peasants' interests and in favour of corporations" (Aquino et al., 2013: 2). ${ }^{16}$ Furthermore, there is a special emphasis in transgenic contamination as an intentional form of "power deviation because the state apparatus was used in favour of private interests" and against communities' food sovereignty (op. cit.: 4-5). The authors of the document conceptualize transgenic contamination as a form of control:

the invasion with transgenic corn has been prepared by the government at the service of corporations that produced and commercialized it ... it is mostly a way of controlling the seeds market in Mexico ... to this end laws have been modified to the benefit of big corporations and to the detriment of small producers, who are then place at the margins of law when they sell or exchange seeds they produce. (Aquino et al., 2013: 4) ${ }^{17}$

Nonetheless, the document also gives examples of how for peasants and indigenous communities the disappearance of corn from Mexican agriculture goes beyond material/economic loss and into the other areas of life: spirituality, history and autonomy. In the document, corn is presented not only as a seed but also 
"as an experience", a deeply human[e] experience that shapes how life is lived and organized (Aquino et al., 2013: 3). This subtle, but nonetheless existing realization, informs the way in which the crime of power deviation in relation to transgenic contamination is considered: Mexico plays as genetic reservoir of corn, but also of the knowledges necessary to keep corn alive (op. cit.: 5). Accordingly, for the authors the crux of the problem is that losing native corn in communities means the end of their autonomy and knowledges preserved for centuries.

The authors also pay special attention to evidence of resistance despite oppressive and systemic forms of violence caused by the state's power deviation. For example, they share the following quote: "Women and men in Oaxaca, we are sowing our corn even against a system that wants to eradicate our Mexican and Oaxaquenio countryside" (op. cit.: 3 ). ${ }^{18}$

The document also privileges what seems to be the authors' interest in carefully pondering why, against all odds, the culture of communities survives due to the organization of life that stems from the milpa (corn fields): "among ourselves we ask why does tequio (communal solidary reciprocate work) survive? Why do communitarian services survive? Why does the system of cargos survive? Why does traditional medicine survive?" (Aquino et al., 2013: 12). There is an acknowledgement that the struggle of indigenous communities for their autonomy, ways of life and government dates back centuries and it is linked to corn.

\section{The coloniality of legal pluralism}

A classical notion of legal pluralism defines it as "the presence in a social field of more than one legal order" and relates to the "ideology of centralism" to debunk the myth of law as an "unified, exclusive and hierarchical order depending on the power of the state" (Griffiths, 1986: 1, 5). In this chapter, the notion of legal pluralism is built upon a critical intercultural approach to law and/or legal pluralism as formulated by Vachon and Coll (1996), Esteva and Prakash (1998), Santos (2002) and Walsh (2012). According to Walsh (2012: 36), legal pluralism is "within this same paradigm [hegemonic western thought] and conceived from a pluricultural interpretation of the sphere of justice that highlights separation and opposition of two or more ways of conceiving and practicing law, one being the 'ordinary' national norm and the other or others the non-ordinary and hence simply added to the established legal structure".

This "adding" is often used to make reference to the "recognition" of "usos y costumbres" (customary law) as rules of "traditional" orders, which are incorporated to "normal" national norms. Accordingly, legal pluralism "seeks to address the problem of legal monism [as] the notion of one single system of rights for all, a principle of the modern uni-national and monocultural State and its normative power to suppress and marginalized difference by establishing one single way of being, knowing and living that is shaped according to the European image and experience" (Walsh, 2012: 33). This is grounded on what Escobar (2012: 16) calls a dominant ontology that is based on Western rationalism's focus on: "[the] belief in logical truth as the only valid (or main) grounds for knowledge about an objective world made up of things that can be known". From this perspective, a normative system, which is not based on objective knowledge, is disregarded or recognized as non-ordinary.

Therefore, for some "opening the legal canon" to non-modern/ colonial practices and systems of justice could be only an act of inclusion but not one that automatically leads to a re-thinking of the monocultural modern/colonial state-centric model of justice (Vachon and Coll, 1996; Santos, 2002; Walsh, 2012).

This is the reason why legal pluralism that does not challenge the racial and modern/colonial structure of the state and its legal field can be seen as part of a rule of law that is accommodated to the multi/pluricultural logic of transnational capitalism and its neo-liberal project (Walsh, 2012: 33). From this perspective, this push for an "integrationist" legal pluralism could be one of the many characteristics of what some conceptualize as "neoliberal multiculturalism" (Hale, 2005). In other words, legal pluralism is not in itself a radical or progressive solution to the question of exclusion of diverse notions, systems and practices of justice, but an instrument that might, or not, contribute to fracturing the exclusionary logic of state law (Santos, 2002).

Therefore, calls for recognition of different systems of justice, including what is call in a modern/colonial relationship "traditional customary law" do not secure a deep transformation of monocultural state-centric notions of justice central to national and international legal systems. Walsh (2012: 34) takes the example of the 2007 UN Declaration on the Rights of Indigenous Peoples and highlights that it brings about new recognitions such as "the intrinsic rights of indigenous peoples that derive from their political, economic, social structures and their cultures, spiritual traditions, history and understanding of life, specially their rights over their lands, territories and resources". However, the differentiation that this declaration establishes between law and collective systems of life and individual-positivist-rationalist law and its Eurocentric modern/colonial/capitalist roots should be pondered carefully because "the firm intention to respect the customs, does not always imply the will to taken away from them from the action of progress, development and civilization under the control of the Nation-State" (Vachon and Coll, 1996: 270).

This call for careful reflection also becomes relevant in relation to the PPT's legal framework, which includes the Universal Declaration of Human Rights, and the Charter of Economic Rights and Duties of States, and in the case of indigenous people and their territories, ILO Convention No 169, as well as the nongovernmental Universal Declaration of the Rights of Peoples. Overall, these frameworks have made important contributions to the formal recognition of indigenous rights but have also important limitations that lead to epistemic violence as erasure of notions of justice that do not and cannot be translated into this legal language or through the rationality that accompanies it. These legal frameworks are based on one model-individualpositivist-rationalist law-that has "silenced the validity of plural legal systems which were colonized by hegemonic powers" (Hernandez et al., 2013: 18).

Another limitation that is rarely considered is the way in which these frameworks fail to contribute to the recognition of different places of legal production besides the nation-state (Walsh, 2012; Hernandez et al., 2013). Indeed, Law, and particularly International Human Rights law, contribute to a systematic invisibility of forms of justice that are produced as secondary, non-universal and residual expressions of the latter and not necessarily implies or secure equality or equity (Assies, 2000 quoted by Walsh, 2012; Gruffydd Jones, 2006). This is the case of "Traditional" and "Customary" law, which are conceived as in need of recognition by Universal institutions and practices to "exist". Less has been said about the fact that these normative systems are at the "margins of state legality" (Walsh, 2012: 34) and, when recognized by the state, then become part of a dispositif "in the technology of power, domestication and domination" (Assies, 2000 quoted by Walsh, 2012; Hernandez et al., 2013).

This has been the case of the Southern Mexican state of Oaxaca, where the PPT hearing on Violence against Corn, Food Sovereignty and Autonomy was held. Oaxaca's first local Constitution dating from 1825 recognized that the state was composed by all the peoples and parties that previously formed the province with that name (Lopez Barcenas, 2005: 54). By 1998, the State of Oaxaca recognized that "indigenous peoples, their 
communities, linguistic groups and afro-descendant communities were subjects of rights, while the recognized rights included their normative systems and indigenous jurisdiction, together with others that already existed such as bilingual and intercultural education, access to justice in State tribunals, to elect authorities through customary electoral system and the free association of municipalities". However, indigenous jurisdiction and the validity of normative systems have been restricted to minor issues (Lopez Barcenas, 2005: 55) and have recently faced important setbacks due to the Mexican state's war on drugs (Hernandez et al., 2013). But nonetheless, and against all odds, these normative systems referred to as "traditional" also "express centuries of resistance to preserve systems of life rooted in territories" (Walsh, 2012: 34). For example, in Oaxaca indigenous people have successfully kept alive their rich diversity of language and culture, while coexisting with their colonizers (Esteva and Prakash, 1998: 111).

This resistance for some is an exercise against colonization and cultural imperialism of the state and its laws, but also of human rights. "For many communities around the world, we are told, human rights are not only alien but incommensurable with existing notions of justice and well-being" (Esteva and Prakash, 1998: 111). Precisely, Esteva and Prakash present a brief description of the notion of justice that is practised in the municipalities of Oaxaca in which 16 different indigenous peoples communities coexist as an example of this incommensurability: " ... their justice do[es] not, for example, look for punishment when a person violates a shared custom. He or she is perceived as someone in trouble, who needs understanding and help; including the opportunity to offer compensations to the victim of his or her misdemeanor .... Rather than confine wrongdoers in jail, many of these communities tie them to trees or confine them to places for a few hours or days with the expressed hope of allowing their passions to calm down ... These practices are not conceived as forms of punishment. Instead they offer communal support ..." (Esteva and Prakash, 1998: 111).

With the example above, I aim to display the ontological difference that grounds Zapoteco indigenous community's normative views. This difference is enunciated from a locus that exceeds modern/colonial Western-rationalist-positivist-individualist experience that informs legal pluralist epistemologies and state-centric legal systems proposals (Escobar, 2012; Vázquez, 2014). ${ }^{19}$

With this background of the debate regarding law and legal pluralism, one can listen to recent calls for "humanizing human rights" and for "new grammars of human dignity" that imply "abandoning the category 'human' ... as [a]globalised localism, as the product of racism" (Suárez Krabbe, 2013: 1).

Despite all of this, in the document produced by Aquino et al. (2013), a brief but nonetheless important observation for the purposes of this chapter's analysis is made: "It is important to note that this demand [the return to the rule of law] is presented by [indigenous] communities that have suffered for over 500 years the perverse use of law instruments against themselves, communities that have suffered not only unfair laws, but laws that have ignored and discriminated them, together with corrupted and racist tribunals" (7). ${ }^{20}$

With this observation, these authors help me to introduce the context in which the struggle for legal pluralism in Mexico is marked by a contentious relationship between State legality and the struggle for indigenous autonomy as a challenge to it. This is the focus of the next section.

\section{Indigenous struggles for legal pluralism and autonomy in Mexico}

Contemporary indigenous peoples struggles in Mexico carry with them a long tradition of resistance against domination and extermination dating back to colonial times. For some, this tradition has influenced and been influenced by local, national and international long-term shifts of the mono-cultural state towards a pluricultural (the Mexican case) or a plurinational one (the Bolivian and Ecuadorian case) (Hernandez et al., 2013; Walsh, 2010).

In this shifting context, the struggle for legal pluralism and autonomy is a more recent one. In Mexico, as in other countries, the demand of indigenous people for state recognition of their existence and of their right to autonomy coincides with the crisis of the nineteenth-century model of the state as a single nation with a culturally homogeneous population (Lopez Barcenas, 2005: 9). This crisis marks in some cases a formal end of assimilationist policies towards indigenous populations but not necessarily of welfare ones.

According to Lopez Barcenas, in the case of Mexico the timeline of indigenous communities struggle for legal pluralism and autonomy started with demands for state recognition of indigenous people as subjects of rights, to the realization of human rights as individual rights, followed by demands for the promulgation of minority rights law to more recent demands for collective rights and autonomy (Lopez Barcenas, 2005: 7). Interestingly, these later demands implied that indigenous peoples in Mexico were recognized as subject of rights, and not mere objects of public welfare, amidst a worldwide (neo-) liberalization trend (Hernandez et al., 2013).

In 1990, Mexico ratified the ILO Convention No 169, and 2 years later, marking the 500 years anniversary of the "Discovery of the Americas", the Federal Constitution of Mexico recognized the existence of indigenous people and the pluricultural nature of the nation. This reformist moment, in all Latin America, will be characterized as a "new multicultural constitutionalism", one that was compatible with the ongoing neo-liberal reforms' emphasis on individual (and/or civil society) responsibility and a smaller state (Van Cott, 2000).

Accordingly, the new conquered recognitions did not mean recognition of the collective rights of indigenous persons as belonging to a specific pueblo (people). The current status of recognition represents a characterization of indigenous individuals as members of minorities who need to be integrated into the larger Mexican society.

This is different from the position taken in other countries in Latin America, such as Ecuador and Bolivia, where recent constitutional reforms have meant the recognition of indigenous peoples as subjects of rights and consequential with this, have granted recognition to the existence in these countries of diverse normative systems. Furthermore, the constitutions of these countries recognize the possibility of exercising rights as individuals or as collectives/communities together with their indigenous systems of justice (Walsh, 2010).

One relevant element that could help us to understand the contrasting reformist outcomes of Mexico and Bolivia/Ecuador is the Zapatista uprising (Lopez Barcenas, 2005). The Mexican state multicultural reformist trend of the 1990s was marked not only by its coherence with ongoing neo-liberal trends, but also by the war against the indigenous-based Ejercito Zapatista de Liberacion Nacional (EZLN) that declared war against the Mexican State and Neo-liberalism on 1 January 1994 (Baronet et al., 2011; Hernandez et al., 2013).

National and transnational demonstrations prompted a cease of fire after just 10 days of war and peace negotiations between the EZLN and the Mexican state started. At the forefront of these negotiations was the question of state recognition of collective rights of indigenous peoples and of their autonomy. By 1996, the San Andres Agreements for Peace were signed between the Mexican state representatives and the EZLN, which included the 
recognition of the right of indigenous peoples to apply their normative systems (Baronet et al., 2011).

However, these agreements were eventually rejected in 2001 by the Executive and transformed by the Legislative power, to the extent that the right to self-determination was recognized as already happening and already expressed in the mere existence of the indigenous communities. The indigenous peoples existence was recognized but not their rights, because these were only recognized to the communities they inhabit (Lopez Barcenas, 2005: 81).

Due to the State rejection of the previously agreed San Andres Agreements of 1996, the EZLN embarked in the creation of de facto autonomous territories with their own judicial, political, economic, educative and health system (Baronet et al., 2011). Up to the early 2000s, the Mexican state not only did not recognize the autonomy of Zapatistas territories (named Caracoles), but also maintained a "low intensity war" despite the official ceasefire of 1994 (CAPISE, 2007; Olivera Bustamante, 2007).

Recent assessments of the experiences of normative, political and security autonomy of the Zapatistas and other indigenous and peasant communities in Mexico note that these emerged as intricately related to two main trends. On the one hand, the state's formal recognition mechanisms and technologies have become novel forms of control and surveillance. On the other hand, the state's war on drugs and drive to protect transnational capital interest on "resource"-rich territories have come with increasing violence against indigenous communities (Hernandez et al., 2013: 16).

\section{Final reflection}

After pondering all the above elements, this final section offers a reflection, rather than a closed answer to the questions of whether the PPTs in Mexico and the present analysis are worthwhile.

From the PPT protagonists themselves-indigenous peoples' communities and their supporters-who are embarked on the struggle for legal pluralism and autonomy, I have learnt that the tribunals are worthwhile despite their (modern/colonial) legalist vocabulary and Eurocentric rationality. For those who emphasize the PPTs as processes that create opportunities of mutual learning among the participants, these have "opened a real communicative process that allowed us to be transformed by such experience" (TPP Capitulo Mexico, 2014: 4). Meanwhile, for others the PPTs are instruments of visibility but little else (see note 10). This is an important, but certainly unpretentious role.

Moreover, contrary to a superficial observation that could simply characterize the PPTs as another form of modern/colonial imposition of a particular gaze over what is supposed to be justice, well-being, life, dignity or social change, the PPT thematic pre-hearing on Violence against Corn, Food Sovereignty and Autonomy seems to point at something more subtle and complex.

As I have indicated before, in the documents produced by this thematic hearing, statements over social media and key conversations held with one of its judges, there exists a fragile but nonetheless highly relevant opening for a coexistence of notions of justices. If we follow the notion of resistance developed by Lugones' decolonial feminism, it is possible to understand that the mere visibility of a coexistence of different notions of justices, or an ecology of normative realities following Santos (2006), in itself represents a crack, a fissure in the supposedly all-encompassing and homogenized modern/colonial system of international law in which the PPT operates.

However, the opening to a plurality of notions and practices of justice is not automatically conducive to a rethinking of the ways in which the PPT organizers and participants perceive justice. Nor does it address the ways in which the very existence of non-punitive justice as the above-mentioned case of Oaxaca illustrates, raises questions about the language, rationality, logics and procedures employed by the PPT with particular attention to its legal translation.

To move towards a critical revision of the universalism of human rights law within the PPT process is a pending and contentious issue given the context of violence against human rights activists and impunity in Mexico. To think and write about this move from the privileged position of Global North academia "compels us to switch our attention not to what is been said but to who is speaking and what for" (Mignolo, 2013). This epistemic position takes the form here of "written words that uncover the road traveled in a dialogical process" with PPT protagonists in Mexico (Icaza, forthcoming). This chosen route could be worthwhile only if it contributes to thinking justice otherwise in a relationship with those at the forefront of the struggles that are taking place in what the Mexican poet and activist Javier Sicilia calls the "graveyard that today is Mexico".

\section{Notes}

1 "We look forward to the moment in which the current impotence, that immobilizes the majority of Mexicans, is transformed into consistent global action". All translations are my own.

2 The title in Spanish is "El despojo y depredación de México. Libre Comercio y desviación de poder como causas de la violencia estructural, la impunidad y la Guerra sucia contra los pueblos de México".

3 On 26 September 2014, 43 male students of the Raul Isidro Burgos Rural Teacher's College went missing in what seems to be a case of forced disappearance committed by local authorities in complicity with drug-trafficking gangs.

4 "La misión del TPP es promover el respeto universal y efectivo de los derechos fundamentales de los pueblos, de las minorías y de los individuos; y su labor se encamina, precisamente, a la construcción de una legislación que proteja tales derechos”. Qué es el Tribunal Permanente de los Pueblos, http://www.tppmexico.org /que-es-el-tpp/.

5 I am deeply thankful to the anonymous reviewer who suggested this idea.

6 Vázquez explains the relevance for decolonial critique of geo-genealogies to stress the site of enunciation. In his view, a geo-genealogy is a genealogy that acknowledges its situated origin, indicating a relationship to a geographically situated origin (Vázquez, 2014: 178).

7 This section is called "Dialogues" to display the exchange of ideas with Mexican academics-activists involved in different forms and to different extents in the PPT. This is not an arbitrary name selection but a concrete epistemic decision that seeks to avoid the term "fieldwork", but, more importantly, the practice of extracting knowledge of people in the Global South for the benefit of academics, like me, based in the Global North. This political/epistemic/ethical position of collaborative research is elaborated further in Barbosa et al. (2015) and Icaza (forthcoming).

8 I am deeply grateful to Gustavo Esteva, Xochitl Leyva and Silvia Marcos for sharing their views on the PPT in Mexico. Of course, all shortcomings and misinterpretations are my responsibility.

9 See: Pre-Audiencia sobre Feminicidio y Violencia de Genero, http://www.tppmexico .org/boletin-de-prensa-preaudiencia-sobre-feminicidio-y-violencia-de-genero/.

10 UNITIERRA OAXACA and Gustavo Leyva are two key references for the postdevelopmental critique to developmentalism.

11 I understand dialogical process in the way Xochilt Leyva speaks about it as a kind of praxis of research as co-labour (collaborative research) in which the written text is a dialogue with the spoken and written word, with visuality, with past and present experiences and with the imagined horizon of autonomy (see Leyva Solano, 2013).

12 Geopolitics of knowledge is used here as expressed by Mignolo (2009: 2) in the form of questions: "who, when, why and where knowledge is generated".

13 “... un crimen que avanza invisible y silencioso. Pues no sólo se trata de que sus resultados sean difuminados y acallados, sino que por su propia naturaleza y mecanismo de comisión se trata de un crimen que, pese a la evidencia empírica resultante, parece no haberse cometido y por ello, sus responsables parecen no serlo".

14 "[E]l Estado usa sus atribuciones y poderes para beneficiar intereses particulares que son contrarios y perjudiciales del interés general por el que debería velar".

15 Thematic hearing on Feminicide and Gender Violence, and thematic hearing on Violence against Corn, Food Sovereignty and Autonomy.

16 " $[\mathrm{P}]$ odemos demostrar con las pruebas que se nos han allegado [que] [s]e ha desviado mediante nuevas leyes y a través de políticas y programas .... [que] están claramente en contra de los intereses campesinos y a favor de las mismas corporaciones".

17 "la invasión de maíz transgénicoque se ha estado preparando desde el gobierno, al servicio de las corporaciones que lo crearon y lo comercializan ... Se trata ante todo de controlar el mercado de semillas en México ... Para este fin, se han estado 
modificando las leyes para beneficio de las grandes corporaciones y perjuicio de los pequeños productores, colocando a éstos al margen de la ley cuando venden o intercambian las semillas que producen".

18 "Los hombres y mujeres oaxaqueños estamos sembrando nuestros maíces aún en contra de un sistema que quiere acabar con el campo oaxaqueño y mexicano".

19 I am deeply grateful to one of the anonymous reviewers who suggested this idea.

20 "Es importante destacar que esta exigencia es presentada por pueblos que han padecido por más de 500 años el uso perverso de los instrumentos jurídicos contra ellos, pueblos que han padecido no solamente leyes injustas, que los ignoran y discriminan, sino tribunales corruptos y racistas".

\section{References}

Assies W (2000) La oficializacion de lo no official: Re-encuentro de dos mundos? Alteridades; 11 (21): 83-96.

Aquino J, Montecinos C and Esteva G (2013) Dictamen que presentan CamilaMontecinos, Joel Aquino y Gustavo Esteva dictaminadores en la Preaudiencia Nacional: Contaminacion Transgenica del Maiz Nativo, celebrada en San Luis Beltran Oaxaca, Oaxaca, los dias 26 y 27 de Abril de 2013. Document available at: http://www.ttpmexico.org, accessed 2 September 2013.

Barbosa L Da C, Icaza R and Ocampo Talero AM (2015) Knowledge about, knowledge with: Dilemmas of researching lives, nature and genders otherwise. In: Harcourt W and Nelson I (eds) Practising Feminist Political Ecologies; Moving Beyond the Green Economy. Zed Books: London, pp 260-285.

Baronet B, Bayo MM and Stahler-Sholk R (coord.) (2011) Luchas "muy otras". Zapatismo y autonomia en las comunidades indigenas de Chiapas. Universidad Autonoma Metropolitana, CIESAS, Universidad Autonoma de Chiapas: Xochimilco, Mexico.

Bergeron S (2006) Fragments of Development: Nation, Gender and the Space of Modernity. The University of Michigan Press: Ann Arbor, MI, pp 156-157.

CAPISE. (2007) Cara de Guerra: Un Ejécito Federal Mexicano, unos Pueblos Indigenas, un Territorio. San Cristobal de las Casas, Chiapas, 16 July 2007. Document available at: http://www.capise.org.mx/cara-de-guerra-un-ejecitofederal-mexicano-unos-pueblos-indigenas-un-territorio/, accessed 16 July 2015.

Escobar A (2012) Notes on the ontology of design (upublished text). Available at: http://sawyerseminar.ucdavis.edu/files/2012/12/ESCOBAR_Notes-on-the-Ontol ogy-of-Design-Parts-I-II-_-III.pdf, accessed 16 July 2015.

Esteva G and Prakash MS (1998) Grassroots Postmodernism: Remaking the Soil of Cultures. Zed Books: London.

Galtung J (1969) Violence, peace and peace research. Journal of Peace Research; 6 (3): 167-191.

Griffiths J (1986) What is legal pluralism? Journal of Legal Pluralism; (24): 1-55. Available at: http://commission-on-legal-pluralism.com/volumes/24/grif fiths-art.pdf, accessed 16 July 2015

Grosfoguel R (2007) The epistemic decolonial turn: Beyond political economyparadigms. Cultural Studies; 21 (2-3): 211-223.

Gruffydd Jones B (ed) (2006) Introduction: International relations, eurocentrism and imperialism. In: Decolonizing International Relations. Rowman and Littlefield Publishers: Plymouth, UK, pp 1-22.

Hale C (2005) Neoliberal multiculturalism: The remaking of cultural rights and racial dominance in central America. Political and Legal Anthropology Review; 28 (1): 10-28.

Hernandez RA, Sieder R and Sierra MT (eds) (2013) Introduccion. In: Justicias indigenas y Estado: violencias contemporaneas. FLACSO/CIESAS: Mexico City, Mexico, pp 11-42.

Icaza R (forthcoming) Testimony of a pilgrimage: Unlearning and relearning with the South. In: Arashiro Z, Melba B, Eugenia D and Marisol RS (eds) Our Voices. Women in Academia Crossing North-South Borders. Lexigton Books, Rowman and Littlefield.

Icaza R (2010) Global Europe, guilty! Contesting EU neo-liberal governance to LatinAmerica. Third World Quarterly; 3 (12): 123-139.

Icaza R and Vázquez R (2013) Social struggles as epistemic struggles. Development and Change; 43 (6): 683-704.

Leyva Solano X (2013) "Y/osotras ¿Mi/nuestras Luchas Epistémicas Creativas?" In Seminario Virtual Internacional (SVI) Creación de Prácticas de Conocimiento desde el Género, los Movimientos y las Redes de la RETOS. Document available at http://www.encuentroredtoschiapas.com.

Leyva X and Speed S (2008) Hacia la investigación descolonizada: nuestra experiencia de co-labor. In: Leyva X, Burguete A and Speed S (coords.) Gobernar (en) la diversidad: experiencias indígenas desde América Latina. Hacia la investigación de co-labor. CIESAS Mexico, FLACSO Ecuador, FLACSO Guatemala: Mexico City, Mexico, pp 34-59.

Lopez Barcenas F (2005) Autonomia y Derechos Indigenas en Mexico. CEIICH-UNAM: Mexico City, Mexico.

Lugones M (1990) Structure/antistructure and agency under oppressions. Journal of Philosophy; 87 (10): 500-507.

Lugones M (2003) Pilgrimages/Peregrinajes: Theorizing Coalitions against Multiple Oppressions. Rowman and Littlefield: Lanham, MD.
Lugones M (2010a) The coloniality of gender. In: Mignolo W and Escobar A (eds) Globalization and the Decolonial Option. Routledge: London, pp 367-390.

Lugones M (2010b) Towards a decolonial feminism. Hypathia; 25 (4): 742-759.

Mignolo W (2003) Historias locales/diseños globales: colonialidad, conocimientos subalternos y pensamiento fronterizo. Ediciones Akal: Madrid, Spain.

Mignolo W (2009) Epistemic disobedience, independent thought and decolonial freedom. Theory, Culture \& Society; 26 (7-8): 159-181.

Mignolo W (2013) Dewesternization, rewesternization and decoloniality: The racial distribution of capital and knowledge. Public Lecture given at the Centre for the Humanities, University of Utrecht, 13 May.

Olivera Bustamante M (2007) Acteal: Los efectos de la Guerra de baja intensidad. In: Hernandez Castillo RA (ed) La Otra Palabra. Mujeres y Violencia en Chiapas, antes $y$ despues de Acteal. CIESAS/IWGIA: Mexico City, Mexico, pp 114-124.

Quijano A (2000) Coloniality of power, ethnocentrism, and Latin America. Nepantla; 1 (3): 533-580.

Santos B de S (2002) Toward a New Legal Common Sense. Law, globalization, and emancipation. Londres: Butterworths.

Santos B de S (2006) The Rise of the Global Left, The World Social Forum and Beyond. Zed Books: London.

Santos B de S (2009) Una epistemología del Sur. La reinvención del conocimiento y la emancipación social. CLACSO and Siglo XXI Editores: Mexico City, Mexico.

Santos B de S, Nunes JA, Meneses MP (2007) Opening up the canon of knowledge and recognition of difference. In: Santos B d S (ed) Another Knowledge is Possible: Beyond Northern Epistemologies. Verso: London, pp XIX-LXII.

Spivak G (1988) Can the subaltern speak? In: Nelson C and Grossberg L (eds) Marxism and the Interpretation of Culture. Palgrave Macmillan: Houndmills \& Londres, pp 271-317.

Suárez Krabbe J (2013) Democratising democracy, humanizing human rights: European decolonial social movements and the alternative thinking of alternatives. Migration Letters; 10 (3): 333-341.

TPP Mexico (2011) Boletin no. 1 del Tribunal Permanente de los Pueblos. Capitulo Mexico. Document available at: http://issuu.com/tppmexico/docs/bolet_n_1_-_ tpp_cap_tulo_m_xico? $e=8898242 / 4280060$, accessed 16 July 2015.

TPP Capitulo Mexico (2012a) Que es el Tribunal Permanente de los Pueblos? Document available at: http://www.tppmexico.org, accessed 18 September 2013

TPP Capitulo Mexico (2012b) Acusacion General de la Sociedad Civi ante el Tribunal Permanente de los Pueblos. Document available at: http://www .tppmexico.org/wp- content/uploads/2013/08/Acusaci\%C3\%B3n-General-Introduc toria-TPP-Cap\%C3\%ADtulo- $\quad \mathrm{M} \% \mathrm{C} 3 \%$ A9xico-Versi\%C3\%B3n-larga-con-8anexos.pdf, accessed 18 September 2013.

TPP Capitulo Mexico (2014) Final ruling. Document available at: http://www .tppmexico.org/final-ruling-permanent-peoples-tribunal-chapter-mexico/, accessed 3 June 2015.

Vachon R and Coll AN (1995) Etnicidad y derecho: Un enfoque diatopico y dialogal del studio y la ensenanza del pluralism juridico. Paper prepared for the VLascasianas Seminars. Instituto de Investigaciones Juridicas de la UNAM, Mexico City, Mexico, 17-19 Mayo 2015.

Vachon R and Coll AN (1996) Etnicidade y derecho: Un enfoque diatópico y dialogal del estudio y la enseñanza del pluralismo jurídico. In: Cifuentes JEO (coord.) Etnicidad y Derecho: un diálogo postergado entre los científicos sociales. V Jornadas Lascasianas. UNAM: México, pp 267-290.

Van Cott DL (2000) The Liquidation of the Past. The Politics of Diversity in Latin America. University of Pittsburgh Press: Pittsburgh.

Vázquez R (2009) Modernity coloniality and visibility: The politics of time. Sociological Research Online; 14 (4). Document available at: http://www. socresonline.org.uk/14/4/7.html, doi:10.5153/sro.1990, accessed 16 July 2015.

Vázquez R (2011) Translation as erasure: Thoughts on modernity's epistemic violence. Journal of Historical Sociology; 24 (1): 27-44.

Vázquez R (2014) Colonialidad y Relacionalidad. In: Borsani ME and Quintero P (comp.) Los desafíos decoloniales de nuestros días: pensar en colectivo. EDUCO/ Universidad Nacional de Comahuep: Neuquen, Argentina, pp 173-196.

Villoro L (1998) Estado plural, pluralidad de culturas. Paidos UNAM: Mexico City, Mexico.

Walsh C (2007) Shifting the geopolitics of critical knowledge: Decolonial thought and cultural studies "others" in the Andes. Cultural Studies; 21 (2\&3): 224-239.

Walsh C (2010) Development as Buen Vivir: Institutional arrangements and (de) colonial entanglements. Development; 53 (1): 15-21.

Walsh C (2012) El pluralismo jurídico: el desafío de la interculturalidad. Nueva America; (133), Jan-Mar: 32-37. Document available at: https://onedrive.live .com/view.aspx?resid=F7451EDDB7D4EE77!400\&app=WordPdf\&authkey= !AGiotzuiOW8JwkQ, accessed 16 July 2015.

\section{Acknowledgements}

I would like to thank the extensive editorial assistance of Gabrielle Simms and Ramon Vera Herrera's critical observations on the political and ethical relevance of my text given 
the context of impunity and repression in which the PPT worked in Mexico. The final version of this article was finalized while undergoing breast cancer treatment and I would like to thank Rolando Vázquez and Wendy Harcourt for their encouragement during the writing process.

\section{Additional Information}

Competing interests: The author declare no competing financial interests.

Reprints and permission information is available at http://www.palgrave-journals.com/ $\mathrm{pal} /$ authors/rights_and_permissions.html
How to cite this article: Icaza R (2015) The Permanent People's Tribunals and indigenous people's struggles in Mexico: between coloniality and epistemic justice? Palgrave Communications. 1:15020 doi: 10.1057/palcomms.2015.20.

(c) (i) This work is licensed under a Creative Commons Attribution 3.0 International License. The images or other third party material in this article are included in the article's Creative Commons license, unless indicated otherwise in the credit line; if the material is not included under the Creative Commons license, users will need to obtain permission from the license holder to reproduce the material. To view a copy of this license, visit http://creativecommons.org/licenses/by/3.0/ 